\title{
Postdigital Brave New World and Its Educational Implications
}

\author{
Julia Mañero ${ }^{1}$
}

Published online: 5 May 2020

(C) Springer Nature Switzerland AG 2020

Keywords Capitalism · Education · Covid-19 · Postdigital · Solidarity · Triage

Besides, we have our stability to think of. We don't want to change. Every change is a menace to stability. That's another reason why we're so chary of applying new inventions. Every discovery in pure science is potentially subversive; even science must sometimes be treated as a possible enemy. Yes, even science. (Huxley 1932: 198)

In a blink of an eye, stability as we have known it has collapsed. Consequences of the coronavirus pandemic reach beyond the realm of public health and impact all aspects of socio-economy (Whitworth 2020); its causes reach deep into our ideologies and social arrangements. According to Noam Chomsky (in Polychroniou 2020), the pandemic could have been prevented, but there was no profit to be made from preventing a potential disaster - so the world did nothing. How similar is this to other threats to our species, such as global warming? Will humankind be able to learn a lesson from the Covid-19 crisis and apply it to other threats to our existence?

As I write these lines on April 11, 2020, in Sevilla, Spain is the third most impacted country in the world, with a staggering death toll of 15,843 people, and the rate of approximately 500 new deaths per day (World Health Organization 2020a). In a country of ca 47 million people, approximately 834,000 job positions have disappeared only during the month of March, generating poverty and despair (RTVE 2020). We are not just dealing with the pandemic but also with attempts to redefine our jobs, manage stress and anxiety associated with isolation, and fight general feelings of powerlessness. Our main strategy against the virus, social distancing, has also caused emotional and economic distancing.

Julia Mañero

julmancon@gmail.com

1 University of Sevilla, Sevilla, Spain 
In our complex, messy and unpredictable postdigital condition (Jandrić et al. 2018), struggle against these disturbing trends develops curious reconfigurations between the digital and the physical sphere. The digital has indeed become 'the master narrative of our world' (Fuller and Jandrić 2019: 215); yet, the biological is more important than ever. Social media have evolved from toys for spending pastime to our essential communication lifelines; digital payments exceed cash flow (Agarwal 2020). Digital devices track people's movements, strongly reminiscing dystopian science fiction movies from the past (Torbet 2020), reviving 'disciplinary diagrams' of surveillance and control (Foucault in Peters et al. 2020). However, these newly minted postdigital reconfigurations between the digital and the physical sphere are far from cast in stone. 'Dialogue through postdigital conversations offers the possibly to unlearn in order to relearn, together; this is hope.' (Jandrić et al. 2018: 173).

\section{solidarity: $\mathbf{n}$.}

[the support that people in a group give each other because they have the same opinions or aims] (Macmillan Dictionary 2020a)

When social ties become uncertain and blurred, human nature surfaces. At the moment of writing this article, while the pandemic in Spain is still in full swing, people have developed many solidarity activities. Together with crowdfunding initiatives to raise money for healthcare equipment in hospitals and vulnerable collectives, there are many creative and supportive initiatives which promote free, open culture, and worldwide solidarity. On April 8, members of ultra-right-wing parties organized YouTube demonstrations, calling for government's immediate dismissal after the end of the state of emergency; their claim was supported by estimated 450.000 people (Portillo 2020). One day later, the Union of Actors and Actresses complained to the Ministry of Culture about their lack of support to cultural sector and organized a cultural strike by symbolic network 'blackout': participants agreed to neither share nor consume cultural content from 23:59 on Thursday April 9 until 23:59 on Saturday April 11 (Archyde 2020; Spain News 2020).

Following Jandrić (2020: 233), 'the Covid-19 pandemic has initiated historically unprecedented levels of collaboration and openness.' When we become aware of interdependence that defines us as human beings, world solidarity emerges. Free sharing of information and research data, which characterizes the pandemic, is a historically unprecedented move towards openness of information and knowledge. Sharing, and especially its breathtaking speed - inherent to virality - is essential for world's quick and efficient response to the pandemic (Peters et al. 2020). Yet, this interdependence, which unites and frees us, also has its dark side. We are simultaneously dealing with virulent behavior in the organic world (Jandrić 2020), and with 'viral modernity' that illustrates the 'role of information and forms of bioinformation in the social world' (Peters et al. 2020: 3).

Easy-to-disseminate fake news, and their viral spread, are among major challenges to our modernity. Misinformation arrives even from governments of large democratic countries, such as the USA, leaving vulnerable citizens in the pandemic without information needed to prevent contagion (Peters et al. 2020). Conspiracy theories that incriminate, stereotype or bias, are used across the ideological spectrum. Companies monetize global panic and endanger public safety by increasing prices of necessary 
products (World Health Organization 2020b). These trends indicate a reconfiguration in complex relationships between knowledge, public health, and bio-informational capitalism, which results from this newest postdigital scenario (Jandrić et al. 2018).

Solidarity means sharing everything we have, not giving out what we have in excess. Covid-19 is a practical case in the point for the well-known theoretical idea: in order to build a solidary, social, and ecological future, we need a fundamentally different kind of economics (Mair 2020). In order to mitigate impacts of the coronavirus, Spain could be the first country in Europe introducing Universal Basic Income on a long-term basis ( $\mathrm{Ng}$ 2020). The general secretary of the government argues that such a measure would imply that households deprived of income as a result of this crisis would receive financial aid (see Mason 2020). Alongside other measures, such as pausing mortgage payments (Togoh 2020), Universal Basic Income could be a decisive policy for economic recovery after the lockdown. Despite public requests, similar Universal Basic Income initiative has been rejected in the UK, whose government believes that its investments in welfare state are sufficient ( $\mathrm{Ng} 2020)$.

Covid-19 pandemic highlights global deficiencies and systemic fragilities. It shows that the world needs free, universal public services: healthcare, education, research, and science, amongst others. Above all, it shows that solidarity emerges from our collective awareness of interdependence among human beings.

\section{triage: $\mathbf{v}$.}

[to decide the order in which patients should be treated] (Macmillan Dictionary 2020a)

[as a noun, the process of deciding which people or things are most important] (Macmillan Dictionary 2020b)

What is the meaning of solidarity when we do not feel interdependence? We are all facing exponential consequences of the neoliberal system, which uses triage practices to decide who deserves to live and who deserves to die. Those who deserve to live are those who will continue to be active and valuable resources to the system. Thus, claims Chomsky (in Polychroniou 2020), shortage of ventilators and other medical supplies is merely a manifestation of the perversions of the neoliberal system. We critique value judgments and political decisions which lack solidarity and empathy, but many of us are not aware that politics also resides in our gaze. Politics happens when we decide to look elsewhere, extending our solidary only towards matters of our immediate concern.

We perform triage when we do not help others to raise their voice and when we fail to make dehumanization visible. Struggling with our own reality, we leave other people behind as if their reality is not a direct consequence of ours. At the Communiars Collective, ${ }^{1}$ we run a cooperation project between University of Sevilla and the nongovernmental organization Open Cultural Center ${ }^{2}$ in Polykastro (Greece). Within this project, I had a chance to experience inhuman and miserable life in the Moria refugee camp in Greece. With 18,000 people staying in a facility built for 3000 people (Eldin 2020), self-isolation in Moria is impossible. Now that the coronavirus is at their

\footnotetext{
${ }^{1}$ See https://communiars.org. Accessed 11 April 2020.

${ }^{2}$ See https://openculturalcenter.org. Accessed 11 April 2020.
} 
doorstep, people are trying to protect themselves producing their own masks and preparing for the worst.

Countries such as Germany and Luxemburg are planning to receive up to 50 migrant children from Greece. While this is a nice gesture which should not be under-valued, there are more than 42,000 people living in overcrowded camps and about $10 \%$ of them are minors (The Associated Press 2020). These people live under unbearable conditions, and waves of anti-migrant violence deprive them from their last glimpses of human dignity: clothing and food (Fallon and Grant 2020). With restrictive migration measures promoted throughout Europe, they need to choose between returning to an almost certain death and trying to survive at the gates of what they see as a dignified and humane future. From this perspective, solidarity implies much more than humanitarian aid; it requires a recognition that we are all equal, and that our struggles are common. According to Paulo Freire, 'the true generosity consists precisely in fighting to destroy the causes which nourish false charity. False charity constrains the fearful and subdued, the "rejects of life", to extend their trembling hands.' (Freire 1970: 45).

In Covid-19, pandemic injustices have become more visible, and distinctions between oppressors and oppressed have become less blurred. According to Freire (1970: 43), 'concern for humanization leads at once to the recognition of dehumanization'; we now have a historic chance to decide 'between being spectators or actors' and 'speaking out or being silent' (48). Chomsky (2020) advises that this is the moment to reflect on our educational system, which is a triage in its own right, where some contents and voices prevail over other contents and voices. As academics and educators, we have an important responsibility: instead of returning to old 'normality,' we need to create a new reality where true interdependence is recognized and solidarity remains true to its essence. Teaching in the age of Covid-19 is an opportunity to advocate for this new social order. So let us grab this opportunity and start working together!

\section{References}

Agarwal, S. (2020). The coronavirus crisis makes it clear: we're not ready for an online-first world. Digital Trends, 28 March. https://www.digitaltrends.com/news/coronavirus-crisis-not-ready-for-an-online-firstworld-analysis/. Accessed 11 April 2020.

Archyde (2020). The world of culture calls off its 48-hour blackout. https://www.archyde.com/the-world-ofculture-calls-off-its-48-hour-blackout/. Accessed 15 April 2020.

Chomsky, N. (2020). It's time to teach children to understand the world. BBVA, 2 April. https://www.bbva. com/en/podcast-noam-chomsky-its-time-to-teach-children-to-understand-the-world/. Accessed 10 April 2020.

Eldin, Y. (2020). Coronavirus: protecting yourself in a migrant camp. BBC News, 31 March. https://www. bbc.com/news/av/world-52095552/coronavirus-protecting-yourself-in-a-migrant-camp. Accessed 10 April 2020.

Fallon, K., \& Grant, H. (2020). Lesbos coronavirus case sparks fears for refugee camp. The Guardian, 11 March. https://www.theguardian.com/global-development/2020/mar/11/lesbos-coronavirus-case-sparksfears-for-refugee-camp-moria. Accessed 11 April 2020.

Freire, P. (1970). Pedagogy of the oppressed. New York: Continuum.

Fuller, S., \& Jandrić, P. (2019). The postdigital human: making the history of the future. Postdigital Science and Education, 1(1), 190-217. https://doi.org/10.1007/s42438-018-0003-x.

Huxley, A. (1932). Brave new world. New York: Harper Brothers.

Jandrić, P. (2020). Postdigital research in the time of Covid-19. Postdigital Science and Education, 2(2), 233238. https://doi.org/10.1007/s42438-020-00113-8. 
Jandrić, P., Knox, J., Besley, T., Ryberg, T., Suoranta, J., \& Hayes, S. (2018). Postdigital science and education. Educational Philosophy and Theory, 50(10), 893-899. https://doi.org/10.1080 /00131857.2018.1454000.

MacMillan Dictionary (2020a). Solidarity. https://www.macmillandictionary.com/dictionary/british/solidarity. Accessed 11 April 2020.

MacMillan Dictionary (2020b). Triage. https://www.macmillandictionary.com/dictionary/british/triage_2. Accessed 11 April 2020.

Mair, S. (2020). How will coronavirus change the world? BBC News, 21 March. https://www.bbc. com/future/article/20200331-covid-19-how-will-the-coronavirus-change-the-world. Accessed 11 April 2020.

Mason, P. (2020). Pablo Iglesias on Spain's plan to introduce a basic income to fight the economic crisis. New Statesman, 9 April. https:/www.newstatesman.com/world/europe/2020/04/pablo-iglesias-spains-planintroduce-basic-income-fight-economic-crisis. Accessed 15 April.

NG, K. (2020). Coronavirus: Spain to become first country in Europe to roll out universal basic income. The Independent, 6 April. https:/www.independent.co.uk/news/world/europe/coronavirus-spain-universalbasic-income-europe-a9449336.html. Accessed 15 April 2020.

Peters, M. A., Jandrić, P., \& McLaren, P. (2020). Viral modernity? Epidemics, infodemics, and the 'bioinformational' paradigm. Educational Philosophy and Theory, 1-23. https://doi.org/10.1080 /00131857.2020.1744226.

Polychroniou, C. J. (2020). Chomsky: ventilator shortage exposes the cruelty of neoliberal capitalism. Truthout, 1 April. https://truthout.org/articles/chomsky-ventilator-shortage-exposes-the-cruelty-ofneoliberal-capitalism/. Accessed 10 April 2020.

Portillo, J. (2020). A virtual 'protest' against the government attracts nearly 450,000 viewers. Huffington Post, 8 April. https://www.huffingtonpost.es/entry/la-primera-manifestacion-virtual-contra-el-gobiernocongrega-cerca-de-450000-espectadores_es_5e8e098cc5b670b4330a7e2b. Accessed 14 April 2020.

RTVE (2020). El coronavirus destruye casi 834.000 empleos en marzo y deja la peor cifra de paro de la historia. https://www.rtve.es/noticias/20200402/coronavirus-destruye-casi-834000-empleos-marzo-dejapeor-cifra-paro-historia/2011275.shtml. Accessed 8 April 2020.

Spain News (2020). 48-hour cultural blackout in the networks against Minister Rodríguez Uribes. https://spainsnews.com/48-hour-cultural-blackout-in-the-networks-against-minister-rodriguez-uribes/. Accessed 15 April 2020.

The Associated Press (2020). Germany, Luxembourg to take in migrant children from Greece. The New York Times, 7 April. https://www.nytimes.com/aponline/2020/04/07/world/europe/ap-eu-europe-migrants. html. Accessed 11 April 2020.

Togoh, I. (2020). Spain to roll out permanent universal basic income 'soon'. Forbes, 6 April. https://www. forbes.com/sites/isabeltogoh/2020/04/06/spain-to-roll-out-permanent-universal-basic-income-soon/\#20f7 d120316f. Accessed 15 April 2020.

Torbet, G. (2020). U.S. government uses mobile location data to track movements during outbreak. Digital Trends, 29 March. https:/www.digitaltrends.com/mobile/government-tracking-mobile-data-coronavirus/. Accessed 11 April 2020.

Whitworth, J. (2020). COVID-19: a fast evolving pandemic. Transactions of the Royal Society of Tropical Medicine and Hygiene, 114(4), 241-248. https://doi.org/10.1093/trstmh/traa025.

World Health Organization (2020a). Spain. https://who.sprinklr.com/region/euro/country/es. Accessed 11 April 2020.

World Health Organization (2020b). Rational use of personal protective equipment for coronavirus disease 2019 (COVID-19): interim guidance. 27 February. https://apps.who.int/iris/bitstream/handle/10665 /331215/WHO-2019-nCov-IPCPPE_use-2020.1-eng.pdf. Accessed 17 April 2020. 